\title{
Tiroit Hormonlarının Yüksek Frekanslı Uyarım ile Tetiklenen Sinaptik Gücün Depotansiyasyonu Üzerine Etkisi
}

\section{The Effect of Thyroid Hormones on Depotentiation of Synaptic Strengthening Which is Induced by High Frequency Stimulation}

iD Burak Tan $^{1}$, iD Ercan Babur $^{2}$, iD Cem Süer $^{1}$, iD Nurcan Dursun $^{1}$

${ }^{1}$ Erciyes Üniversitesi, Tıp Fakültesi, Fizyoloji Anabilim Dalı, Kayseri, Türkiye

${ }^{2}$ Tokat Gaziosmanpaşa Üniversitesi, Tıp Fakültesi, Fizyoloji Anabilim Dalı, Tokat, Türkiye

$\ddot{\mathbf{O} z}$

Amaç: Önceki çalışma bulgularımız, normal tiroit hormon düzeylerinin sinaptik plastisitenin göstergeleri olan uzun dönemli güçlenme (UDG) ve uzun dönemli baskılanma (UDB) yanıtları arasındaki dengenin oluşmasında rol oynayabileceğini göstermektedir. Sinaptik plastisitenin bir diğer formu olan depotansiyasyon (DP) ise şu ana kadar bu bağlamda çalışılmamıştır. Bu çalışmada, tiroid hormonları ile sinaptik plastisite arasındaki ilişkiyi anlamak için, hipokampüse infüze edilen T4 ve T3 hormonlarının DP büyüklüğünü değiştirip değiştirmediği araştırılmıştır.

Gereç ve Yöntem: Deneyler, yüksek frekanslı uyarım (YFU) sırasında SF, T4 ve T3 infüze edilen ve düşük frekanslı uyarım (DFU) sırasında SF, T4 ve T3 infüze edilen 2 aylık Wistar albino erkek sıçanlardan oluşan (n=7/grup) 3 grup olarak gerçekleştirildi. Depotansiyasyonu indüklemek için, YFU kalıbı olarak 1 sn süreli 100 Hz frekanslı 4 tekrarlı uyarımı takiben 5 dk sonra, DFU kalıbı olarak $1 \mathrm{~Hz}$ frekanslı 900 pulse uyarım kullanıldı. Böylece uyarılan nöron havuzundaki sinapslarda hem yeni sinaps oluşumu hem de silinmesi elektriksel olarak tetiklendi ve kayitlandi.

Bulgular: T4 hormonunun YFU sırasında uygulanmasının popülasyon spike (PS) genliğini kontrol grubuna göre değiştirdiği ( $p<0,001)$, DFU sırasında uygulanmasının ise etkilemediği ( $>0,05)$ bulundu. T4 hormonunun YFU veya DFU sırasında uygulanmasının eksitatör postsinaptik potansiyel (EPSP) eğimindeki zamansal değişimlerinin ve T3 hormonunun YFU veya DFU sırasında uygulanmasının PS genliği ve EPSP eğimindeki zamansal değişimlerinin SF infüzyonu yapılanlar ile aynı olduğu bulundu.

Sonuç: Bu sonuçlar, T4'ün YFU sırasında uygulanmasının DP yanıtı üzerinde anlamlı bir etkiye sahip olduğunu, DFU sırasında T4 uygulanmasının ise, DP yanıtı üzerinde anlamlı bir etkiye sahip olmadığını düşündürmektedir.

Anahtar Kelimeler: Sinaptik plastisite, Depotansiyasyon, Tiroit hormonları, Hipokampüs

Abstract

Objective: Our previous study findings showed that normal thyroid hormone levels may play a role in the balance between long-term potentiation (LTP) and long-term depression (LTD) that are indicative of synaptic plasticity. Depotentiation (DP), another form of synaptic plasticity, has not been studied in this context so far. In the present study, we aimed to learn the effect of infused T4 hormone on the depotentiation magnitude and the relationship between T4 and synaptic plasticity.

Material and Method: Experiments were performed in 3 groups of 2-month-old Wistar albino male rats (n=7/group) infused with SF, T4 and T3 during high frequency stimulation (HFS) or during low frequency stimulation (LFS). Depotentiation was induced by a HFS (100Hz,1 sec, 4 times), followed by LFS (900-pulse stimulation at 1 Hz). Thus, both synapse formation and deletion were electrically triggered and recorded in synapses of the stimulated neuron pool.

Results: It was found that infusion of T4 during HFS decreased the PS amplitude compared to that control group ( $p<0.001$ ), but infusion during LFS did not affect it ( $p>0.05$ ). It was found that the temporal changes in the EPSP slope of the infusion of T4 during HFS or LFS and the temporal changes in the PS amplitude and EPSP slope of the infusion of T3 during HFS or LFS were the same as the SF infusion.

Conclusion: These results suggested that the application of T4 during HFS have a significant effect on DP but the application of T4 during LFS does not seem to have a significant effect on DP.

Key words: Synaptic plasticity, Depotentiation, Thyroid hormones, Hippocampus

Yazışma Adresi: Burak Tan, Erciyes Üniversitesi, Tıp Fakültesi, Fizyoloji Anabilim Dalı, Melikgazi/KAYSERI

E-Posta: burak_tan49@hotmail.com

Alınma tarihi: 21.01.2021 / Kabul tarihi: 10.03.2021 / Yayımlanma tarihi: 15.12.2021

Tiroid Hormonlarının Depotansiyasyon Üzerine Etkisi - Tan ve ark. 
deney hayvanlarına acı vermemek için etik ilkelere özen gösterildi.

Hücresel düzeyde öğrenme ve bellek, sinyal yolağındaki nöronlarda bazı sinapsların güçlenmesi (uzun dönemli güçlenme: UDG) (1), bazılarının ise gerilemesi ve silinmesi (uzun dönemli baskılanma: UDB) (2) sonucunda gerçekleşmektedir. Deneysel olarak uygun uyarım kalıpları ile oluşturulan UDG ve UDB sırasıyla yeni sinaptik bağlantılar oluşumu veya var olanların silinmesi sonucunu doğurur. Depotansiyasyon (DP) ise deneysel olarak yüksek frekanslı uyarım ile indüklenerek güçlendirilen sinapsların daha sonrasında uzun süreli düşük frekanslı uyarımla tekrar bazal koşullara döndürülmesini ifade eder (3). Bu bağlamda, DP sinaptik plastisitenin stabilizasyonu için önemli rol oynar.

Demansla karakterli pek çok hastalıkta, sinaptik plastisitedeki bozuklukların rolü vurgulanmaktadır. Vakaların çoğunda, bilişsel bozulmanın kesin nedeni bilinemez ve bu bilişsel kayıplar, ölüme kadar götürebilen patolojilere neden olabilir (4). Bu hastalıklarda hipokampüs en önemli beyin bölgelerinden biridir ve demansa neden olan veya bu nedeni tetikleyen faktörler yaygın araştırma konusu olmuştur (5).

Son çalışmalar, sinaptik plastisitenin, gelişimin ilk aşamalarında ve yetişkinlik döneminde tiroit hormonu düzeylerindeki azalma ve yükselmelerden etkilenebileceğini göstermiştir. Yetişkin sıçanlarda azalmış ve artmış serum T4 seviyelerinin dentat girus granül hücre morfolojisinde değişikliklere yol açar. Bu değişiklikler özellikle hipotiroidi drurumunda hipertiroidiye göre daha belirgindir $(6,7)$. Bu çalışmalar doğrultusunda, yetişkin dönemde oluşan distiroidizmin, öğrenme performansı ve sinaptik plastisite üzerinde benzer etkiler ortaya çıkarmaktadır. Distiroidizm tablosunda, hipokampal UDG'nin bozulduğu ve ilginç bir şekilde $(8,9)$, hipotiroidide hipokampal UDB'nin daha kolay meydana geldiği bildirilmiştir (10). Son zamanlardaki çalışma bulgularımız, hipertiroidinin de hipokampal UDB'nin daha kolay indüklenmesine yol açtığını göstermiştir (11)ÿK $\notin \mathrm{D} \mu$. Bu bulgular, intrahipokampal tiroksin infüzyonu ile laboratuvarımızda yapmış olduğumuz diğer çalışmalarla da doğrulanmıştır (12). Bu çalışmaların sonuçları doğrultusunda, UDG ve UDB arasındaki dengeyi korumak için fizyolojik tiroit hormon seviyelerine ihtiyaç olduğu sonucuna varılabilir. Sinaptik plastisitenin daha üst düzey formu olan DP ise şu ana kadar bu bağlamda çalışılmamıştır. Bu çalışma, tiroit hormonları (TH) ve bilişsel bozulma arasındaki ilişkiyi daha iyi anlayabilmek amacıyla, sinaptik bağlantı oluşması ve silinmesi arasındaki dengeyi TH'nin sinaptik silinme yönünde değiştirip değiştirmediğini araştırmıştır. Bu çalışmadan elde edilen bulgular, daha önceki çalışmalarımıza göre tiroksin hormonun genomik olmayan bir mekanizma ile UDG yanıtlarında azalmaya ve UDB yanitlarında bir stabiliteye neden olan etkisini tamamlar niteliktedir. UDG'nin yeni bilginin öğrenilmesi sürecinin; UDB ve DP'nin ise unutma sürecinin altında yatan temel mekanizmalar olduğu dikkate alınarak, bu bulguların Alzheimer hastalığı gibi bilişsel bozulmalarla karakterli hastalıkların patogenezinin açıklanmasında önemli olacağı düşünülmektedir.

\section{Materyal ve Metod}

\section{Deney Hayvanları}

$\mathrm{Bu}$ çalışma Erciyes Üniversitesi Hayvan Deneyleri Yerel Etik Kurulunun (HADYEK) 12.03.2014 tarih ve 14/037 say1l onayı ile gerçekleştirildi. Çalışmada gereksiz deney hayvanı kullanmamak ve
Çalışma için Erciyes Üniversitesi Hakan Çetinsaya Deneysel ve Klinik Araştırma Merkezi'nde (DEKAM) üretilen Wistar albino cinsi 42 adet 200-250 gr ağırlığında 60 günlük erkek sıçan kullanıldı. Sıçanlar musluk suyu ve standart sıçan yemi ile kısıtlama yapılmaksızın beslendi. Sıçanlar; Kontrol (K, n=14), T3 infüze edilmiş (T3, $n=14)$ ve T4 infüze edilmiş (T4, n=14) olmak üzere 3 gruba ayrıldı.

\section{Cerrahi İșlemler}

Hipokampüs dokusuna belirlenen miktarda tiroid hormonlarını (T3 ve T4) infüze etmek ve elektrofizyolojik kayitlama yapabilmek için sıçanlar anastezi edilip stereotaksik çatıya yerleştirildi. Anestezinin sağlanması için her hayvana $1,2 \mathrm{~g} / \mathrm{Kg}$ intraperitonal olarak üretan enjeksiyonu yapıldı. Stereotaksik çatıya (Kopf Instruments, Tujunga, CA, USA) sıçanlar kulak ve ağız çubukları vasıtasıyla kafalarından sabitlendi, kafa saçlı derisi ve deri altı dokuları prensiplere uygun olarak orta hat kesisi ile açıldı. Bu işlem, stereotaksik çatı üzerinde yapıldı. Saçlı deri retrakte edildi, sağ hemisfer üzerindeki kemik yapıda oval pencere şeklinde bir delik açıldı ve kanamadan arındırıldı. Daha sonra lambda ve bregmanın aynı düzlemde olmaları "düzlem ayarlama çubuğu" vasıtasıyla sağlandı. Paxinosand ve Watson (1998) sıçan beyin atlası kullanılarak, bregma referans noktası alınıp uygun koordinatlara, uyarı ve kayıt-infüzyon elektrotları ile girildi.

\section{Elektrofizyoloji ve Tiroit Hormon İnfüzyonu}

Cerrahi prensiplere uygun olarak yapılan sağ kranyotomiden sonra bir bipolar elektrot (Teflon kaplı, paslanmaz çelik, $127 \mu$ m çaplı, ucu dışında izole edilmiş) vasıtasıyla medyal perforan yol (bregmaya göre mm; AP: -8.0, ML: 4.2) uyarıldı. Uyarıcı elektrotun iki kutbu düşük dirençli kablolar ile bir uyarım izolatörüne (A385, World Precision Instruments, USA,) bağlandı. Dış çapı $1,5 \mathrm{~mm}$ ve uzunluğu $10 \mathrm{~mm}$ olan çift kanallı borosilikat kapiller tüplerden (World Precision Instruments) dikey bir mikropipet çekici (P30, Sutter Instrument Co, USA) ile hazırlanan çift kanallı bir cam mikropipet (uç direnci 2-10 $\mathrm{M} \Omega$ ), ipsilateral dentat girusun granül hücre tabakasına (bregmadan mm olarak: AP: 3,5 - ML: 2,15 - DV: 2,5-3 mm duradan aşağıya) girildi. Kanallardan biri $3 \mathrm{M} \mathrm{NaCl}$ ile dolduruldu ve cam elektrottan eksitatör postsinaptik alan potansiyelleri kaydedildi. T4 grubunun mikropipet 2.kanalına $100 \mathrm{nmol} \mathrm{T4}$ doldurulup, diğer grubun ikinci kanalına ise 100 pikomol T3 (Sigma, CAS:51-48-9) T3 dolduruldu ve bir Hamilton enjektörü yardımıyla 15 dakika dentat girusun granül hücre tabakasına infüze edildi. $\mathrm{Bir} \mathrm{Ag}-\mathrm{AgCl}$ disk elektrot boyun derisi altına yerleştirildi ve referans elektrot olarak kullanıldı. Kayıt elektrodunun $3 \mathrm{M} \mathrm{NaCl}$ doldurulan kanalının içine yerleştirilen klorlanmış bir gümüş tel ve referans elektrodu bir "head-stage" kullanılarak tek kanal epitelyal voltaj/akım kıskaç yükseltecine (VCC600, Physiological Instruments) bağlandı. Bütün sistem bir Faraday kafesi kullanılarak topraklandı.

Hem uyarıcı hem de kayıt elektrodu, pozitif yönlü bir sapmayı (EPSP) takip eden negatif yönlü bir sapma (PS) elde edilene kadar derin yapılara indirildi. Granül hücre tabakasının tipik yanıtı elde edilmeye başlandığında elektrotların derinlikleri $0,1 \mathrm{~mm}$ artırılarak en büyük cevap elde edildi. Bütün deneyler sonucu ortalama elektrot derinlikleri uyarıcı elektrot için 2,5 mm kayıt elektrodu için $3 \mathrm{~mm}$ idi.

Kayıt bölgesi yukarda açıklandığı gibi bulunduktan sonra sinyalin dengeye ulaşması beklendi. Bu işlem 15 dakika boyunca yapıldı ve bu 
sürede dentat girus nöronları, $0,033 \mathrm{~Hz}$ frekansında elektrik uyarımla $(0,5 \mathrm{~mA}, 0,175 \mu$ s süreli) uyarıldı. Daha sonra, $0-15$ nci dakikalar arasında yüksek frekanslı uyarım (YFU) kalıbı kullanılarak $(100 \mathrm{~Hz}$, 1 sn, 4 kez) uzun dönemli güçlenme tetiklendi ve 20-22nci dakikalar arasında düşük frekanslı uyarım (DFU) kalıbı kullanılarak (1 Hz, 900 puls, 900 sn) depotansiyasyon indüklendi. Tiroit hormonlarının infüzyonu bazı deneylerde DP indüksiyonundan önceki 5 dakika ya da 55-60'nc1 dakikalar arasında uyguland1.

\section{Veri Analizi ve İstatistik}

EPSP dalgasının eğimi, dalganın başlangıcı ve PS dalgasının başlangıcı arasındaki voltaj farkının \%20-80 arasında hesaplandı. PS genliği ilk pozitif yükseltiden sonraki negatif yönlü dalga arasındaki farktan hesaplandı. Başlangıçtaki 15 dakikalık sürede tetiklenen 30 alan potansiyelinin EPSP ve PS'lerinden oluşan ortalama eğim ve genlik değerleri 100 kabul edildi; YFU ve DFU sonrasındaki her EPSP ve PS bunun yüzdesi cinsinden hesaplandi. UDG'nin indüksiyonu için YFU'dan sonraki $10 \mathrm{dk}$ süresince oluşan eğim ve genliklerin; idame dönemi için ise son 10 dakikalık bölümde oluşan eğim ve genlik değerlerinin ortalamaları alındı. UDB'nin indüksiyonu için DFU'dan sonraki 10 dakikada oluşan eğim ve genliklerin; idame dönemi için ise son 10 dakikalık bölümde oluşan eğim ve genlik değerlerinin ortalamaları alındı. İstatistik karşılaştırmalar için, çoklu grupların tek ölçümlü verilerinin karşılaştırılmasında tek-yönlü ANOVA, çok ölçümlü verilerin karşılaştırılmasında tekrarlayan ölçümlerle ANOVA testleri, ikili karşılaştırmalarda ise post-hoc Tukey testi kullanıldı. Anlamlılık düzeyi $\mathrm{p}<0,05$ olarak seçildi.

\section{Bulgular}

\section{T4 hormon infüzyonunun depotansiyasyon üzerine etkisi}

T4 infüzyonu için, depotansiyasyon kayıtları süresince alınan EPSP eğimleri Şekil 1A'da, PS genlikleri ise Şekil 1C'de sunulmuştur. Bütün gruplar, hem EPSP eğiminde $\left(\mathrm{F}_{2,21}=1,03 ; \mathrm{P}>0,05\right)$ hem de PS genliğinde $\left(\mathrm{F}_{2,21}=0,56 ; \mathrm{P}>0,05\right)$, benzer YFU sonrası artış oranı ve DFU sonras1 azalma oranı gösterdiler. Bununla birlikte, DFU sonras1 EPSP eğimi $\left(\mathrm{F}_{2,21}=4,25 ; \mathrm{P}=0,028\right)$ ve PS genliği $\left(\mathrm{F}_{2,21}=4,08 ; \mathrm{P}\right.$ $=0,032$ ) üzerinde anlamlı grup etkisi bulunmuştur (Şekil 1B: EPSP, Şekil 1D: PS). PS genliği sadece T4'ün YFU sırasında infüze edilen grupta, bazal değerin $\% 174,3 \pm 13.8$ değerinden $\% 101,5 \pm 17$, 1 'ine depotansiye olurken, EPSP eğimi hem SF (\%143,0 $\pm 1,9$ en $\% 101,2$ $\pm 8,2$ ye; $\mathrm{P}=0,015)$ ve hem de T4'ün YFU sirasinda infize edilen gruplarda (YFU'dan önce infüze edilenlerde $\% 114,7 \pm 13,3 \%$ den $\% 66,5 \pm 13,7$ 'ye, $\mathrm{P}=0,026$ ) anlamlı düzeyde bir depotansiyasyon gösterdi. T4 hormonu DFU sırasında infüze edildiğinde PS genliğinde $(\% 191,2 \pm 14,0$ 'den $\% 185,4 \pm 18,5$ 'e; $\mathrm{P}>0,05)$ ve EPSP eğiminde $(\% 128,5 \pm 15,3$ den $\% 105,7 \pm 8,8$ 'e; P > 0,05) anlamlı bir depresyon oluşmadı. Bu sonuçlar, EPSP eğimi ile temsil edilen var olan sinapslardaki amplifiye edilmişs sinaptik gücün veya etkinliğin zayıflamasının T4 hormonu ile ortadan kaldırılabileceğini göstermektedir.

Tiroid Hormonlarının Depotansiyasyon Üzerine Etkisi - Tan ve ark.

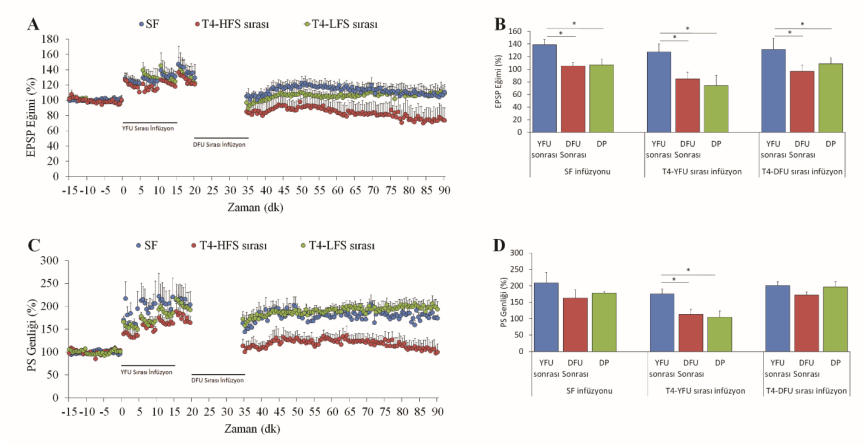

Şekil 1. T4 hormon infüzyonunun depotansiyasyon yanıtları üzerine etkisi. A: Deney süresinde kaydedilen EPSP eğimleri. B: EPSP eğimlerine ait YFU sonrası, DFU sonrası ve idame döneminin son 5 dk'lık kısmı (DP)'nın ortalamaları. C: Deney sürsince kaydedile populasyon spike genlikleri. D: PS genliklerine ait YFU sonras1, DFU sonrası ve idame döneminin son 5 dk'l1k kısmı (DP)'nın ortalamaları. Değerler ortalama \pm standart hata olarak verildi. * kontrol grubuna göre anlamlı farklılığı ifade eder.

\section{T3 hormon infüzyonunun depotansiyasyon üzerine etkisi}

T3 infüzyonu için, depotansiyasyon kayıtları süresince alınan EPSP eğimleri Şekil 2A'da, PS genlikleri ise Şekil 2C'de sunulmuştur. Bütün gruplar, hem EPSP eğiminde $\left(\mathrm{F}_{2,21}=0,51\right.$ ve 0,$\left.53 ; \mathrm{P}>0,05\right)$ hem de PS genliğinde $\left(\mathrm{F}_{2,21}=0,80\right.$ ve 0,$\left.99 ; \mathrm{P}>0,05\right)$, benzer YFU sonrası artı̧̧ oranı ve DFU sonrası azalma oranı gösterdiler (Şekil 2B: EPSP, Şekil 2D: PS). Bununla birlikte, PS genliği sadece DFU sırasında T3 infüze edilen grupta bazal değerin $\% 135 \pm 18.5$ ' ine kadar depotansiye olurken, EPSP eğimi hem SF (143.0 \pm \%12.9 den $101.2 \pm$ $\% 8.2 ; \mathrm{P}=0.015$ ) hem de T3 infüze edilen gruplarda depotansiyasyon gösterdi (YFU sırası infüzyonda: \%128,6 \pm 9,2'den \%89,8 $\pm 15,1$ 'e, $\mathrm{P}=0,046$; DFU siras1 infüzyonda: $\% 130,6 \pm 10,1$ den $\% 85,5 \pm$ 9,7'ye, $\mathrm{P}=0,009)$. $\mathrm{Bu}$ sonuçlar, önceden var olan sinapslarda güçlendirilmiş sinaptik kuvvetin veya etkinliğin zayıflamasının T3 hormonu tarafından değiştirilmediğini göstermektedir. Bununla birlikte, sinaptik olmayan bir plastisiteyi yansıtan PS genliği üzerine T3 hormonunun etkisi olduğu görülmektedir.
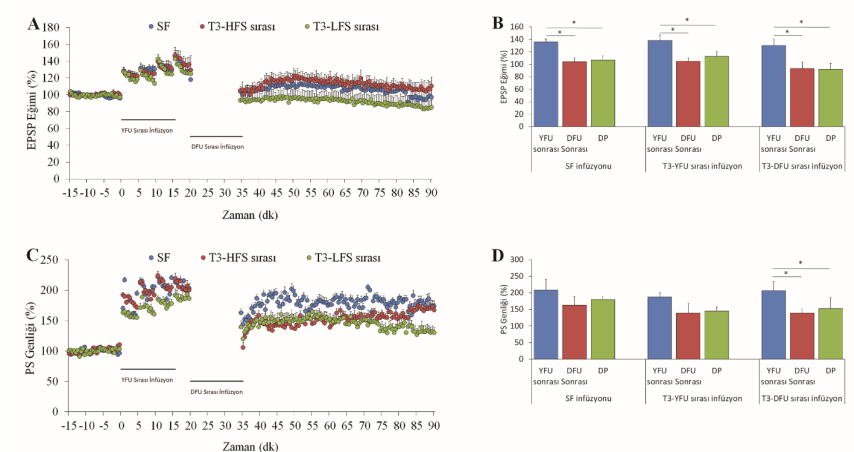

Şekil 2. T3 hormon infüzyonunun depotansiyasyon yanıtları üzerine etkisi. A: Deney süresinde kaydedilen EPSP eğimleri. B: EPSP eğimlerine ait YFU sonrası, DFU sonrası ve idame döneminin son 5 dk'lık kısmı (DP)'nın ortalamaları. C: Deney sürsince kaydedilen populasyon spike genlikleri. D: PS genliklerine ait YFU sonras1, DFU sonrası ve idame döneminin son $5 \mathrm{dk}$ 'l1k k1smı (DP)'nın ortalamaları. Değerler ortalama \pm standart hata olarak verildi. * kontrol grubuna göre anlamlı farklılığı ifade eder. 
T4 ve T3 Hormonunun Depotansiyasyon Üzerine Etkisinin Karşılaştırılması

Sinaptik plastisitenin uzun vadedeki değişimlerini gözlemlemek için, bu çalışmada YFU'yu takiben uygulanan DFU uygulandı ve DFU'yu takiben 1 saat süresince oluşan DP yanıtları (idame dönemi) kaydedildi. Uzun vadedeki değişimlerin istatistiksel analizleri için, idame döneminin son 5 dk'lık DP yanıtları analiz edildi (Şekil 3). Tek yönlü ANOVA testi ile yapılan karşıllaştırmalarda EPSP eğimleri için gruplar arası anlamlı farklılık olmadığ 1 ( $p>0,05$, Şekil 3A), PS genlikleri için gruplar arası anlamlı farklılık olduğu bulundu $\left(\mathrm{F}_{4,34}=3,442 ; \mathrm{p}=0,020\right.$, Şekil 3B). İkili karşılaştırmalar için, tek yönlü ANOVA testini takiben yapılan post-hoc Tukey testi YFU sırasinda T4 infüze edilen grupta depotansiyasyon yanıtlarına (idame döneminin son 5 dakikalık kısmı) ait PS genliğinin SF infüze edilen ve DFU sırasında T4 infüze edilen gruplara göre anlamlı düzeyde daha düşük olduğunu gösterdi (sırasıyla, $\mathrm{p}=0,40$ ve $\mathrm{p}=0,13$ ).
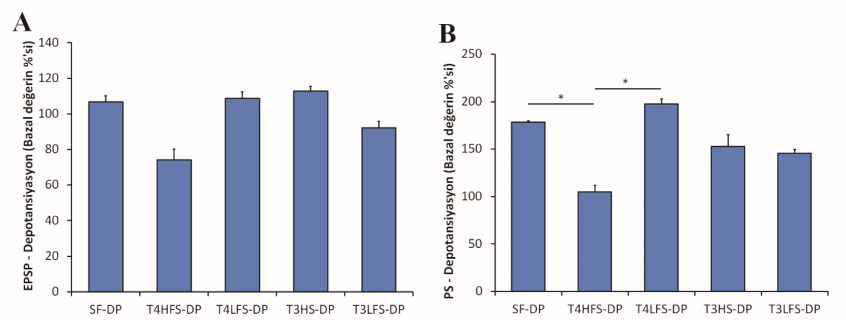

Şekil 3. T4 ve T3 hormonlarının depotansiyasyon yanıtları üzerine etkilerinin karşılaştırılması. A. Depotansiyasyon (DP: idame döneminin son 5 dakikalık kısmı) yanıtlarına ait EPSP eğimleri B: Depotansiyasyon yanıtlarına ait PS genlikleri. Değerler ortalama \pm standart hata olarak verildi. * gruplar arası anlamlı farklılı̆̆ 1 ifade eder.

\section{Tartıșma}

Çalışma bulgularına göre, EPSP eğim değerlendirmesinde SF, T4 ve T3 infüze edilen hipokampüslerde DFU sonrası anlamlı düzeyde baskılanma olduğu bulundu. PS genlikleri için, SF infüzyonunun DFU uygulaması sonrasında PS genliğini azaltmadığı, T4 infüzyonunun YFU sırasında PS genliğini önemli derecede azalttığı, DFU sırası T4 infüzyonunun ise PS genliğini önemli derecede değiştirmediği belirlendi. T3'ün ise PS genliği için DFU sırası infüzyonun depotansiyasyon oluşturduğu fakat YFU sırası infüzyonunun depotansiyasyon oluşturmadığı görüldü.

Dentat girus granüler hücre somalarından kayıtlanan alan potansiyellerinden EPSP bileşeni aferent yolla uyarılan nöron grubunun PS, bileşeni ise membran potansiyeli bir eşik değere yükselerek aksiyon potansiyeli oluşturabilen hücre grubunun elektriksel özelliklerini yansıtır (13). UDG'nin indüklenmesi sırasında T4 hormon infüzyonunun EPSP eğiminde görülen artışı SF infüze edilen gruba göre anlamlı bir şekilde etkilemediğini; ancak PS genliğinde SF infüze edilen gruba kıyasla güçlenmeyi azalttığını göstermiştir. PS genliği açısından indüksiyon döneminde güçlenmede görülen azalmanın idame döneminde de devam ettiği, bu nedenle her iki grupta da YFU protokolünden sonra aferent yolla uyarılan hücre populasyonunun ve bunlardan eşik değere kadar depolarize olarak aksiyon potansiyeli oluşturan nöron populasyonunun arttığı ancak bu artışın L-tiroksin grubunda anlamlı olarak daha düşük olduğunu görülmektedir. Daha önceki bir çalışmamızda, on beş dakika süreyle
100 pM T4 infüzyonunun hipokampal UDG'yi azalttığı UDB'yi ise kolaylaştırdığını bildirdik. Dahası, bu etkileri tiroit hormon reseptör analoğu olan tetrac'ın tersine çevirdiğini gösterdik (12). $\mathrm{Bu}$ çalışmanın verileri, T4'ün, integrin $\alpha v \beta 3$ reseptörü aracılığıyla UDG üzerinden UDB'yi destekleyebileceğine ve endojen T4'ün bu reseptör üzerindeki etkisinin hipokampüste tetrac tarafindan engellenebileceğine dair in vivo kanıt sağlamaktadır (12). Mevcut ve önceki çalışma bulgularımız, Caria ve ark. (14) tarafından yapılan çalışma bulguları ile de uyumludur. Bu çalışma bulguları, lokal T4 uygulamasının alan EPSP'lerini engellediğini ortaya koymuştur. Dahası, kronik olarak T4 veya T3 hormonu uygulaması ile oluşturulan deneysel hipertiroidizmin UDG ve UDB yanıtlarını değiştirdiği çeşitli çalışmalarda bildirilmiştir $(1,9,15-17)$.

Tiroit hormonları ile nörotransmitterler, yapısal proteinler, büyüme faktörleri ve diğer proteinler arasındaki ilişkiler incelenmiş ve TH'nin nöronal gelişimi önemli ölçüde etkilediği gösterilmiştir (18). Tiroit seviyesine göre meydana gelen moleküler değişiklikler detaylı şekilde çalışılmıştır. Hipokampal CA1 bölgesindeki piramidal hücrelerde TH'ye yanıt olarak dendritik spin dansitesinde değişikliklerin olduğu ve tiroit hormonlarının çeşitli nörotrofik faktörlerin ekpresyonunu ve reseptör populasyonunun düzenlenmesini etkilediği gösterilmiştir (19). Hem gelişim döneminde hem de yetişkinlikte TH reseptörleri ve mRNA'larının dağılımı tespit edilmiştir $(15,20)$. Tiroit hormonları birçok farklı biyolojik süreçleri etkilemektedir. Bu etkilerini genomik veya non-genomik yol olmak üzere iki farklı yoldan gösterirler. Tiroit hormonlarının non-genomik etkileri nükleustaki tiroit hormon reseptör (TR) aracılığıyla gerçekleştirilen transkripsiyonel regülasyonun düzenlenmesiden (genomik yol) çok daha hızlıdır $(21,22)$.

Tiroit hormonları non-genomik etkileri ortaya çıkarmak için çok sayıda yolağı etkilemektedir (21-25). Tiroit hormonlarının non-genomik etkisi plazma membranında, sitoplazmada ve hücre organellerinde tanımlanmıştır. $\mathrm{Bu}$ etkiler; $\mathrm{Na}^{+}, \mathrm{K}^{+}, \mathrm{Ca}^{2+}$ un düzenlenmesi, glukoz transportu, ERK/MAPK, PKC ve PKA'nın aktivasyonu, PLC ve PLD'nin aktivasyonu ile fosfolipid metabolizmasının düzenlenmesi şeklinde sıralanabilir (26). İn vitro yapılan çalışmalar ile protein sentezinden bağımsız olarak T4'ün IP3 ve kalsiyum sinyal iletimini

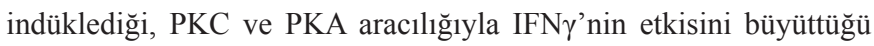
gösterilmiştir (27-29). Ayrıca plazma membranını geçemeyen agaroza bağlı T4'ün G proteini eşlikli tiroit hormon membran reseptörünün etkisiyle MAPK'y1 aktive ettiği gösterilmiştir (30). Hücre kültürü çalışmaları tiroit hormonlarının hızlı ve non-genomik olarak $\mathrm{Ca}^{2+}$ ATPaz enziminin, PKC aracılığıyla $\mathrm{Na}^{+}$kanalının $\left(\mathrm{I}_{\mathrm{Na}}\right)$, PI3-kinaz aracılığıyla $\mathrm{K}^{+}$kanalının $\left(\mathrm{I}_{\mathrm{K}}\right)$, PKC ve MAPK aracılığıyla $\mathrm{Na}^{+} / \mathrm{H}^{+}$anti-port sisteminin ve içeri doğrultucu potasyum kanalının $\left(\mathrm{I}_{\mathrm{K} 1}\right)$ fonksiyonlarını düzenlediğini göstermektedir (23).

Davis ve diğerlerininönerdikleribirmodelde, tiroithormonlarınınhücre yüzeyiyle düzenlenen non-genomik etkisini G-proteini aracılığıyla MAPK ve PI3-kinaz sinyal iletim kaskadı ile gerçekleştirdiğini ileri sürmektedir $(30,31)$. Bu modele göre, 10-30 dakikalık bir zaman zarfında T4 hücre yüzey GPCR'sine bağlanır (30), tirozin fosforilasyonu, MAPK'ın aktivasyonu ve nükleusa translokasyonu ile sonuçlanan PKC, Ras, Rafl ve MEK'1 aktifleştirir ve sırayla TR'nin uzantısındaki bir serin kalıntısını fosforiller $(32,33)$. Bu fosforilasyon TR'nin ko-repressör SMRT ve NCoR'den ayrılmasıyla, azalmış proteaz aktivitesiyle ve transkripsiyon aktivitesinde artışla sonuçlanır (34-36) ve RXR heterodimerizasyonunu düzenler (37). Nükleer MAPK/TR kompleksinin transkripsiyonel aktiviteyi düzenlemek için p53'e bağlandığı ve fosforile ettiği de gösterilmiştir (33). Paralel bir 
yolakta, T4 tarafindan aktive edilen MEK, nükleer translokasyona, daha sonra MAPK tarafindan serin fosforilasyonuna ve gen transkripsiyon aktivasyonuna neden olan STAT1 ve STAT3'deki tirozin kalıntılarını fosforiller (30). Böylece tiroit hormonunu nongenomik olarak STAT, p53 ve TR olmak üzere en az üç farklı yolak tarafindan gen transkripsiyonunu etkiler. Bu şekilde yapılmış olan çalışmalar tiroit hormonunu non-genomik etkisinin çok yaygın olduğunu ve birçok farklı hücre tipinde çok sayıda fizyolojik süreçleri kapsadığııı göstermektedir.

Sonuç olarak, EPSP eğim değerlendirmesinde SF infüzyonu, YFU sırasında ve DFU sırasında T4 ve T3 infüze edilen hipokampüslerde DFU sonrası tüm gruplarda UDG' de önemli baskılanma olduğu yani T4 ve T3 infüzyonunun depotansiyasyon yanıtlarının EPSP eğimlerinde önemli etki göstermediği sonucuna varılabilir. Yüksek frekanslı uyarım sırasında T4 infüzyonunun DFU sonrasında PS genliğini SF infüzyonuna göre azalttığ 1 , DFU sırasında T4 infüzyonunun ise PS genliğini etkilemediği belirlendi. Yüksek frekanslı uyarım sırasında T3 infüzyonunun DFU sonrasında PS genliğini SF infüzyonuna göre azaltmadığı, DFU sırasında T3 infüzyonunun ise PS genliğini SF infüzyonuna göre azalttığı belirlendi. Bu sonuçlar, önceden var olan sinapslarda güçlendirilmiş sinaptik kuvvetin veya etkinliğin EPSP yanıtlarındaki zayıflamanın T4 veya T3 hormonu tarafindan değiştirilmediğini göstermektedir. Bununla birlikte, sinaptik olmayan bir plastisiteyi yansıtan PS genliği üzerine T4 hormonunun etkisi olduğu görülmektedir.

\section{Kaynaklar}

1.Bliss TV, Lømo T. Long-lasting potentiation of synaptic transmission in the dentate area of the anaesthetized rabbit following stimulation of the perforant path. The Journal of physiology 1973;232:331-56

2.Dudek SM, Bear MF. Homosynaptic long-term depression in area CA1 of hippocampus and effects of N-methyl-D-aspartate receptor blockade. In: ed. editor^editors., World Scientific, 1995 Date: p. 200-4.

3.Barrionuevo G, Schottler F, Lynch G. The effects of repetitive low frequency stimulation on control and "potentiated" synaptic responses in the hippocampus. Life sciences $1980 ; 27: 2385-91$

4.D Skaper S, Facci L, Zusso M, et al. Synaptic plasticity, dementia and Alzheimer disease. CNS \& Neurological Disorders-Drug Targets (Formerly Current Drug TargetsCNS \& Neurological Disorders) 2017;16:220-33

5.Wang F, Geng X, Tao H-Y, et al. The restoration after repetitive transcranial magnetic stimulation treatment on cognitive ability of vascular dementia rats and its impacts on synaptic plasticity in hippocampal CA1 area. Journal of molecular neuroscience 2010;41:145-55

6.Martí-Carbonell MA, Garau A, Sala-Roca J, et al. Effects of adult dysthyroidism on the morphology of hippocampal granular cells in rats. Acta Neurobiol Exp 2012;72:230-9

7.Sala-Roca J, Estebanez-Perpina E, Balada F, et al. Effects of adult dysthyroidism on the morphology of hippocampal neurons. Behavioural brain research 2008;188:348-54

8.Taşkın E, Artis AS, Bitiktas S, et al. Experimentally induced hyperthyroidism disrupts hippocampal long-term potentiation in adult rats. Neuroendocrinology 2011;94:218-27

9.Pavlides C, Westlind-Danielsson A, Nyborg H, et al. Neonatal hyperthyroidism disrupts hippocampal LTP and spatial learning. Experimental brain research 1991;85:559-64

10.Alzoubi K, Aleisa A, Alkadhi K. Adult-onset hypothyroidism facilitates and enhances LTD: reversal by chronic nicotine treatment. Neurobiology of disease 2007;26:264-72

11.Tan B, Bitiktaş S, Kavraal Ş, et al. Low-frequency stimulation induces a durable long-term depression in young adult hyperthyroid rats: the role of p38 mitogen-activated protein kinase and protein phosphatase 1. Neuroreport 2016;27:640-6

12.Bitiktaş S, Tan B, Kavraal Ş, et al. The effects of intra-hippocampal L-thyroxine infusion on long-term potentiation and long-term depression: A possible role for the $\alpha v \beta 3$ integrin receptor. Journal of neuroscience research 2017;95:1621-32

13.Chaudhury D, Wang LM, Colwell CS. Circadian regulation of hippocampal long-term potentiation. Journal of biological rhythms 2005;20:225-36

14.Caria MA, Dratman MB, Kow LM, et al. Thyroid hormone action: nongenomic modulation of neuronal excitability in the hippocampus. Journal of neuroendocrinology 2009;21:98-107

15.Bradley DJ, Young WS, Weinberger C. Differential expression of alpha and beta thyroid hormone receptor genes in rat brain and pituitary. Proceedings of the National Academy of Sciences 1989;86:7250-4

16.Gilbert M, Sui L. Dose-dependent reductions in spatial learning and synaptic function in the dentate gyrus of adult rats following developmental thyroid hormone insufficiency. Brain research 2006;1069:10-22

17.Artis A, Bitiktas S, Taşkın E, et al. Experimental hypothyroidism delays field excitatory post-synaptic potentials and disrupts hippocampal long-term potentiation in the dentate gyrus of hippocampal formation and Y-maze performance in adult rats. Journal of neuroendocrinology 2012;24:422-33

18.Dutar P, Bassant M-H, Senut M-C, et al. The septohippocampal pathway: structure and function of a central cholinergic system. Physiological reviews 1995;75:393-427

19.Gould E, Allan MD, McEwen BS. Dendritic spine density of adult hippocampal pyramidal cells is sensitive to thyroid hormone. Brain research 1990;525:327-9

20.Cook CB, Kakucska I, Lechan RM, et al. Expression of thyroid hormone receptor beta 2 in rat hypothalamus. Endocrinology 1992;130:1077-9

21.Bassett J, Harvey CB, Williams GR. Mechanisms of thyroid hormone receptor-specific nuclear and extra nuclear actions. Molecular and cellular endocrinology 2003;213:1-11

22.Davis PJ, Davis FB. Nongenomic actions of thyroid hormone. In: ed. editor^editors., Springer, 2003 Date: p. 19-37.

23.Davis PJ, Davis FB. Nongenomic actions of thyroid hormone on the heart. Thyroid 2002; 12:459-66

24.Davis PJ, Davis FB, Cody V. Membrane receptors mediating thyroid hormone action. Trends in Endocrinology \& Metabolism 2005;16:429-35

25.Shi YB, Wong J, Puzianowska-Kuznicka M, et al. Tadpole competence and tissuespecific temporal regulation of amphibian metamorphosis: Roles of thyroid hormone and its receptors. Bioessays 1996;18:391-9

26.Kavok NS, Krasilnikova OA, Babenko NA. Thyroxine signal transduction in liver cells involves phospholipase $\mathrm{C}$ and phospholipase D activation. Genomic independent action of thyroid hormone. BMC cell biology 2001;2:5

27.Davis PJ, Davis FB, Lawrence WD. Thyroid hormone regulation of membrane Ca2+ATPase activity. Endocrine research 1989;15:651-82

28.Lakatos P, Stern PH. Evidence for direct non-genomic effects of triiodothyronine on bone rudiments in rats: stimulation of the inositol phosphate second messenger system. Acta endocrinologica 1991;125:603-8

29.Lin H-Y, Yen PM, Davis FB, et al. Protein synthesis-dependent potentiation by thyroxine of antiviral activity of interferon- $\gamma$. American Journal of Physiology-Cell Physiology 1997;273:C1225-C32

30.Lin H-Y, Davis FB, Gordinier JK, et al. Thyroid hormone induces activation of mitogen-activated protein kinase in cultured cells. American Journal of Physiology-Cell Physiology 1999;276:C1014-C24

31.Storey NM, O'Bryan JP, Armstrong DL. Rac and Rho mediate opposing hormonal regulation of the ether-a-go-go-related potassium channel. Current Biology 2002;12:2733

32.Davis PJ, Shih A, Lin H-Y, et al. Thyroxine promotes association of mitogenactivated protein kinase and nuclear thyroid hormone receptor (TR) and causes serine phosphorylation of TR. Journal of Biological Chemistry 2000;275:38032-9

33. Shih A, Lin H-Y, Davis FB, et al. Thyroid hormone promotes serine phosphorylation of 553 by mitogen-activated protein kinase. Biochemistry 2001;40:2870-8 
34.Jones K, Brubaker J, Chin W. Evidence that phosphorylation events participate in thyroid hormone action. Endocrinology 1994;134:543-8

35.Leitman DC, Costa CH, Graf H, et al. Thyroid hormone activation of transcription is potentiated by activators of cAMP-dependent protein kinase. Journal of Biological Chemistry 1996;271:21950-5

36. Ting Y-T, Bhat MK, Wong R, et al. Tissue-specific stabilization of the thyroid hormone $\beta 1$ nuclear receptor by phosphorylation. Journal of Biological Chemistry 1997;272:412934

37.Katz D, Reginato MJ, Lazar MA. Functional regulation of thyroid hormone receptor variant TR alpha 2 by phosphorylation. Molecular and cellular biology 1995;15:2341-8 